\title{
THE ACCURACY AND THE PRINTING RESOLUTION COMPARISON OF DIFFERENT 3D PRINTING TECHNOLOGIES
}

\author{
Ewelina Kluska, Piotr Gruda, Natalia Majca-Nowak \\ Aviation Systems, Engineering Design Center \\ Al. Krakowska 110/114, 02-256 Warsaw, Poland \\ ewelina.kluska@ge.com,piotr.gruda@ge.com,natalia.majca@ge.com
}

\begin{abstract}
The article presents a research conducted with the project: 'Additive technology used in conduction with optical methods for rapid prototyping of 3D printed models' [13]. In this article selected three different 3D printing technologies: Fused Deposition Modeling (FDM), Selective Laser Sintering (SLS) and Material Jetting (MJ). Each of them was tested paying special attention to accuracy and resolution of printed elements. Accuracy tests were conducted on the reference specimens which also showed material texture. These specimens were scanned to verified dimensional deviations of printing methods. Printing resolution was verified on a heat exchanger model which was characterized by complicated structure. The highest accuracy and printing resolution was noticed in the MJ technology, PolyJet method on the Objet Eden 260 VS printing machine and the SUP 707 water soluble support material.
\end{abstract}

Keywords: 3D printing, accuracy, printing resolution, complicated shapes.

\section{INTRODUCTION}

The purpose of this article was selected a technology and a material from three different 3D printing methods with the highest accuracy and printing resolution. Moreover, there were considered cost of machine, materials and service costs. The revision was created in particular to analyse of complicated shapes by the best parameters for each $3 \mathrm{D}$ printing method for the accessible printing machines. These technologies were typed considering literature and information contained in manufacturer brochures. Nonetheless, the aim this article is not only theoretical considering about this method but using the best practise. 


\section{3D PRINTING METHODS}

\subsection{FDM technology}

Based on the information from $[1,7,8]$ the FDM technology is the most common due to price and simplicity. The FDM uses extruded polymer from heated head printer and impose it layer by layer. Afterwards polymer harden itself. The printing process takes place in a heated chamber to avoid material shrinkage and shape deformations. A support material is provided from another printer head and leach out after the printing process. A filament is rolled up on an interchangeable coil. The most common materials are ABS (acrylonitrile butadiene styrene) and PLA (polylactide).
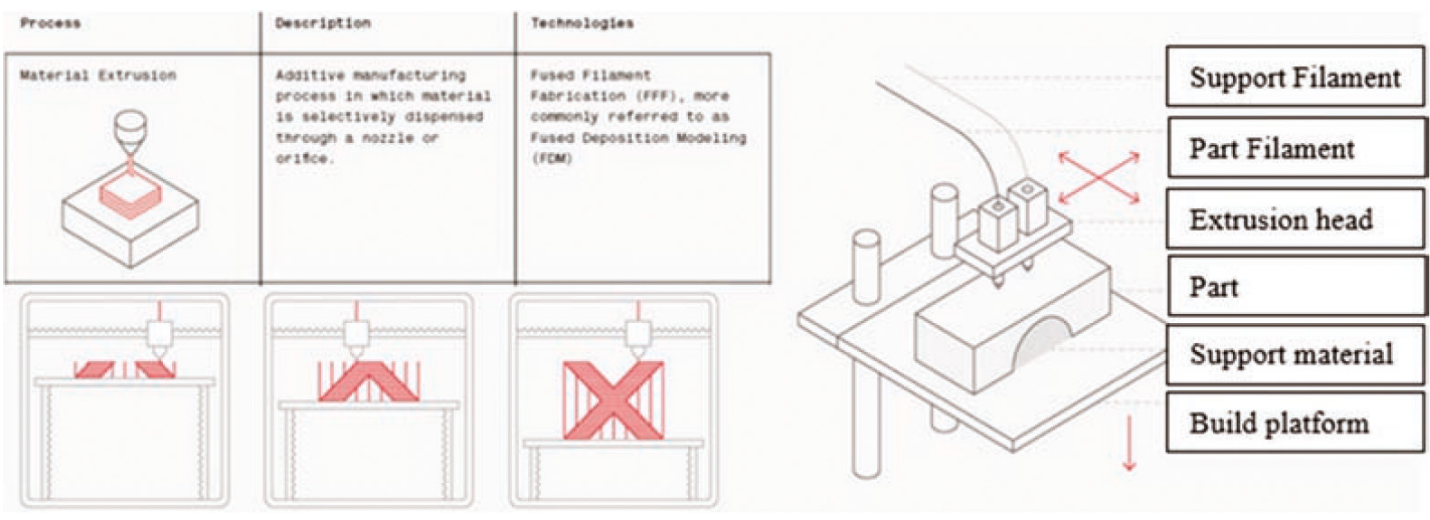

Figure 1. The FDM printing process and schematic of the printer [2]

\subsection{SLS technology}

The SLS is the 3D printing technology were used laser to sinter powder material [3,6,8]. A model is built in the heated chamber filled with a powder material which is both main and support material. The most common powders are PA12 (polyamide) and PS (polystyrene). A support material is removed by compressed air. This method is mainly used to low-volume production.
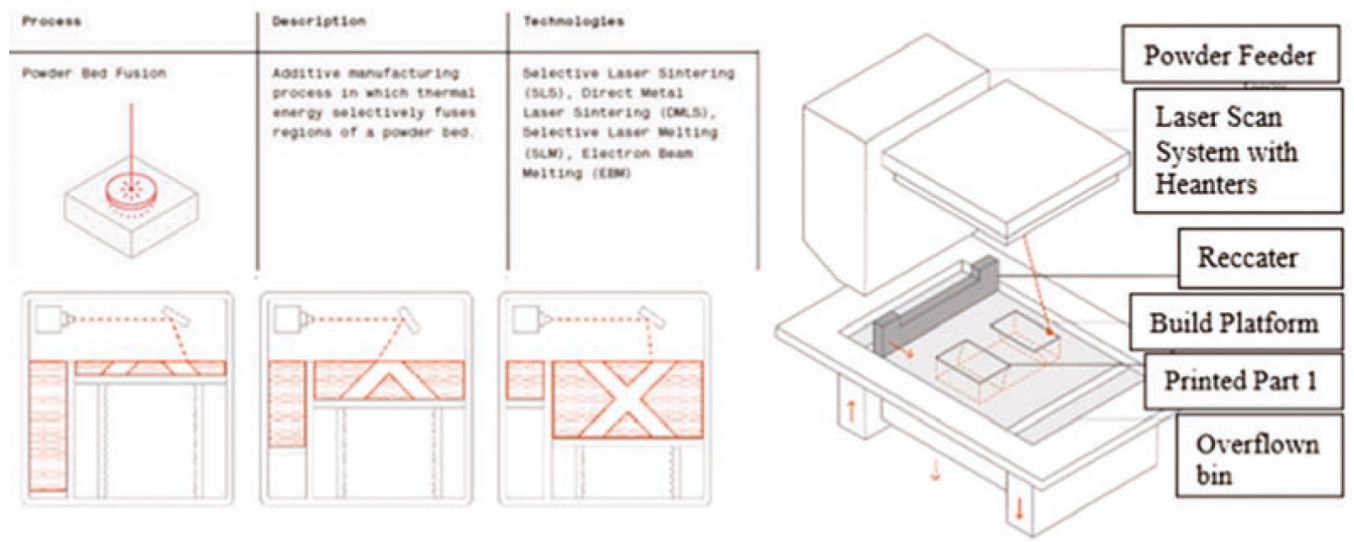

Figure 2. The SLS printing process and schematic of the printer [2] 


\subsection{Material Jetting technology}

The MJ technology $[4,5,12]$ includes two main methods: the PolyJet from Stratasys and the ProJet from 3DSystems. Both methods use UV light to cure photopolymer extruded from the piezoelectric head in the shape of fine drops. A model is built from thin layers (16-32 $\mu \mathrm{m})$. A support material is extruded from another part of head and can be removed using heat, hot water, oil or alkaline solution. The MJ technology has a wide range of polymers and it allows to mix them to create new digital materials which are characterised by different textures and properties. Moreover, this is one of the most accurate $3 \mathrm{D}$ printing method.
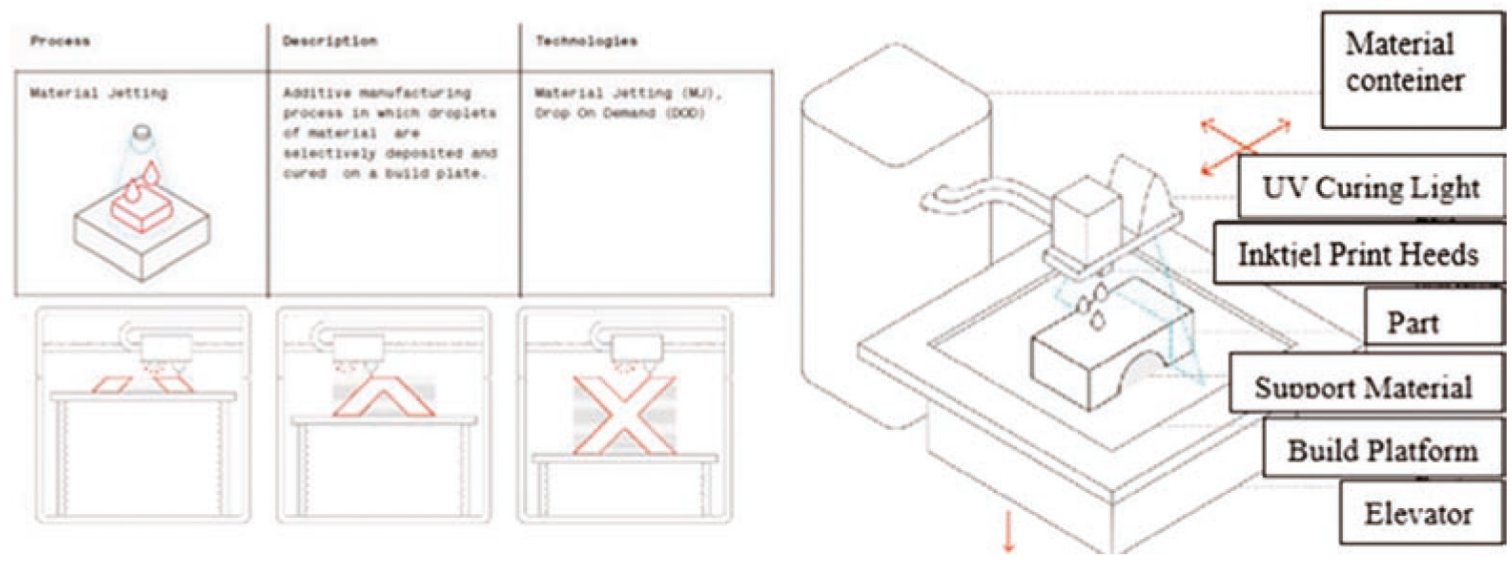

Figure 3. The MJ printing process and schematic of the printer [2]

\section{COMPARISON OF ACCURACY}

Each test was conducted on three specimens in two different specimens' shape. Next, the specimens were scanned using the 3D Steinbichler Comet L3D scanner with nominal measurement accuracy of machine equal to $10 \mu \mathrm{m}$. Specimens scans were superimposed on the $3 \mathrm{D}$ model from a CAD software to verify a dimensional deviation of printed specimens.

\subsection{Geometric analysis - FDM technology}

The first step was to test specimens in the FDM technology [9]. The reference specimens were printed on the Fortus $250 \mathrm{mc}$ machine produced by the Stratasys company. Models were able to print in $0.330 \mathrm{~mm}, 0.254 \mathrm{~mm}$ or $0.178 \mathrm{~mm}$ thicknesses. The nominal printing machine accuracy is $\pm 0.241 \mathrm{~mm}$. Three dumbbell specimens (see Figure 4) and three rectangular prism specimens with hole (see Figure 5) were printed with a different nominal layer thickness $(0.254 \mathrm{~mm}$ and $0.178 \mathrm{~mm})$ [11]. All scan results were gathered in Table 1 and demonstrate on the pictures below (see from Figure 6 to Figure 9). It was noticed for all specimens that one of the biggest flat surfaces is more deformed than other ones. 

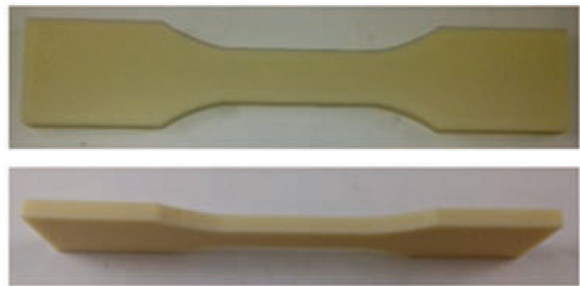

Figure 4. Printed dumbbell specimen (high: $210 \mathrm{~mm}$ )

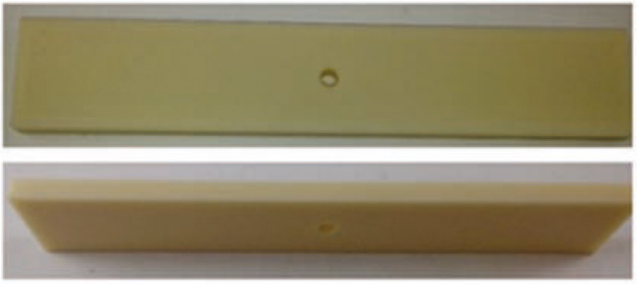

Figure 5. Printed rectangular prism with hole specimen (high: $210 \mathrm{~mm}$ )

Table 1. The minimum and maximum accuracy deviation of dumbbell specimen printed with different thickness layer in FDM technology

\begin{tabular}{|l|c|c|c|c|}
\hline $\begin{array}{l}\text { FDM technology } \\
\text { nominal } \\
\text { accuracy } \mathbf{0 0 , 2 4 1} \\
\mathbf{m m}\end{array}$ & $\begin{array}{c}\text { Dumbbell specimen } \\
\text { layer thickness } \\
\mathbf{0 . 1 7 8} \mathbf{~ m m}\end{array}$ & $\begin{array}{c}\text { Dumbbell specimen } \\
\text { layer thickness } \\
\mathbf{0 . 2 5 4} \mathbf{~ m m}\end{array}$ & $\begin{array}{c}\text { Rectangular prism } \\
\text { with hole specimen } \\
\text { layer thickness } \\
\mathbf{0 . 1 7 8} \mathbf{~ m m}\end{array}$ & $\begin{array}{c}\text { Rectangular } \\
\text { prism with hole } \\
\text { specimen layer } \\
\text { thickness } \\
\mathbf{0 . 2 5 4} \mathbf{~ m m}\end{array}$ \\
\hline $\begin{array}{l}\text { Maximum } \\
\text { deviation }[\mathrm{mm}]\end{array}$ & +0.163 & +0.346 & +0.205 & +0.353 \\
\hline $\begin{array}{l}\text { Minimum } \\
\text { deviation }[\mathrm{mm}]\end{array}$ & -0.160 & -0.298 & -0.359 & -0.198 \\
\hline
\end{tabular}

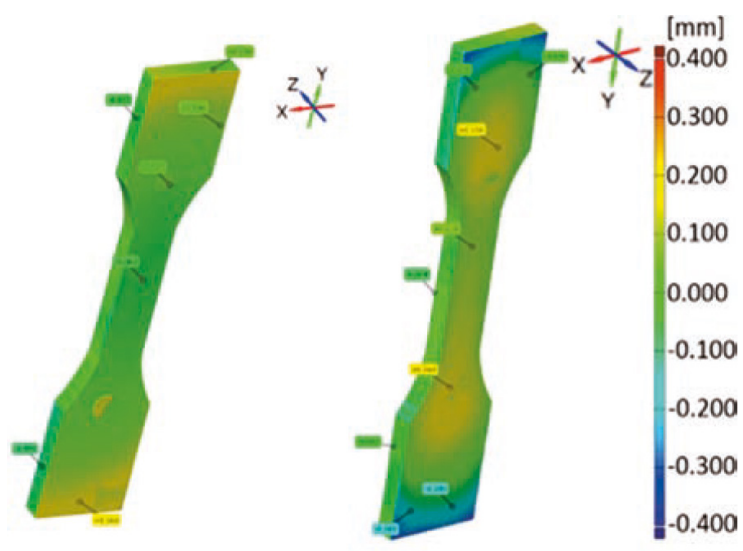

Figure 6. The dumbbell specimen scan printed with nominal layer thickness $0.178 \mathrm{~mm}$ (FDM) 


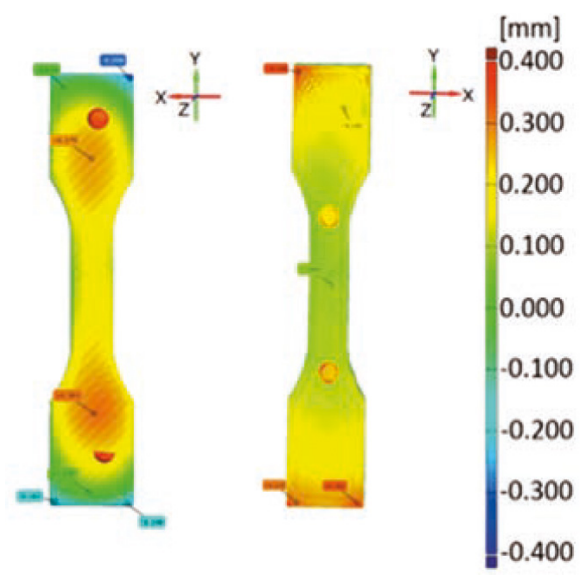

Figure 7. The dumbbell specimen scan printed with nominal layer thickness $0.254 \mathrm{~mm}$ (FDM)
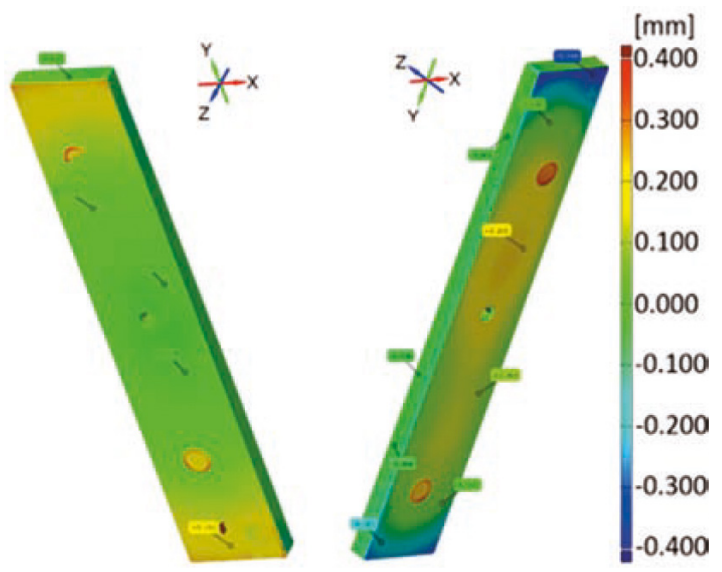

Figure 8 . The rectangular prism with hole specimen scan printed with nominal layer thickness $0.178 \mathrm{~mm}$ (FDM)
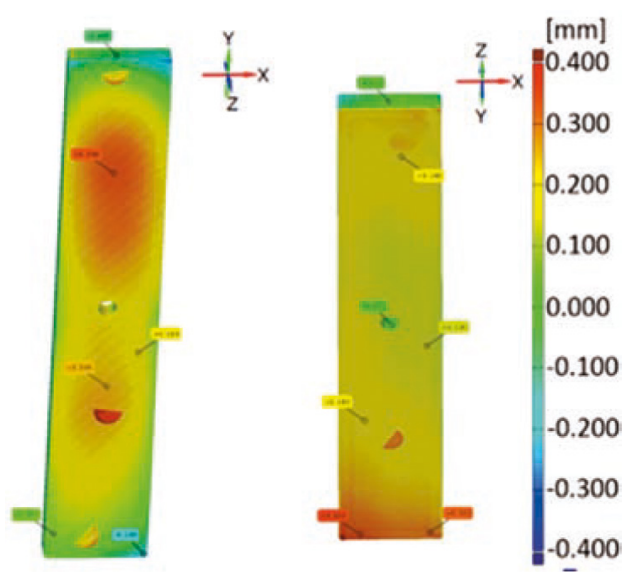

Figure 9. The rectangular prism with hole specimen scan printed with nominal layer thickness $0.254 \mathrm{~mm}$ (FDM) 
The following phase in an investigation was to check an accuracy of three-dimensional specimens after tests on the flat ones. It was printed one cylinder (Figure 10) and one bionic specimen (Figure 11) and an air turbine head specimen. The specimens were printed with the nominal layer thickness $0.254 \mathrm{~mm}$ on the same printer as the flat specimens. All results are gathered in Table 2 .

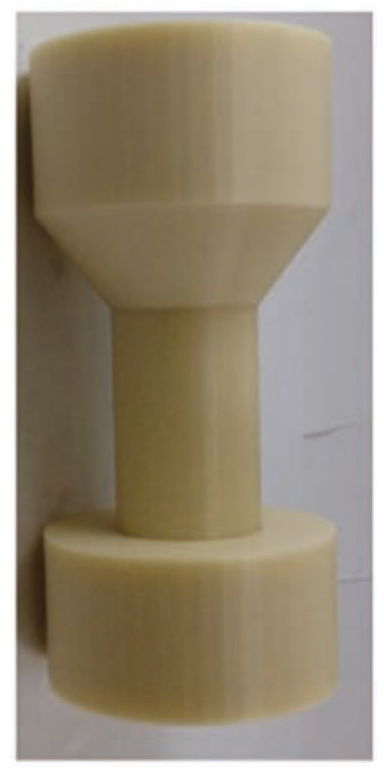

Figure 10. The printed three-dimensional cylinder specimen (high: $160 \mathrm{~mm}$ )

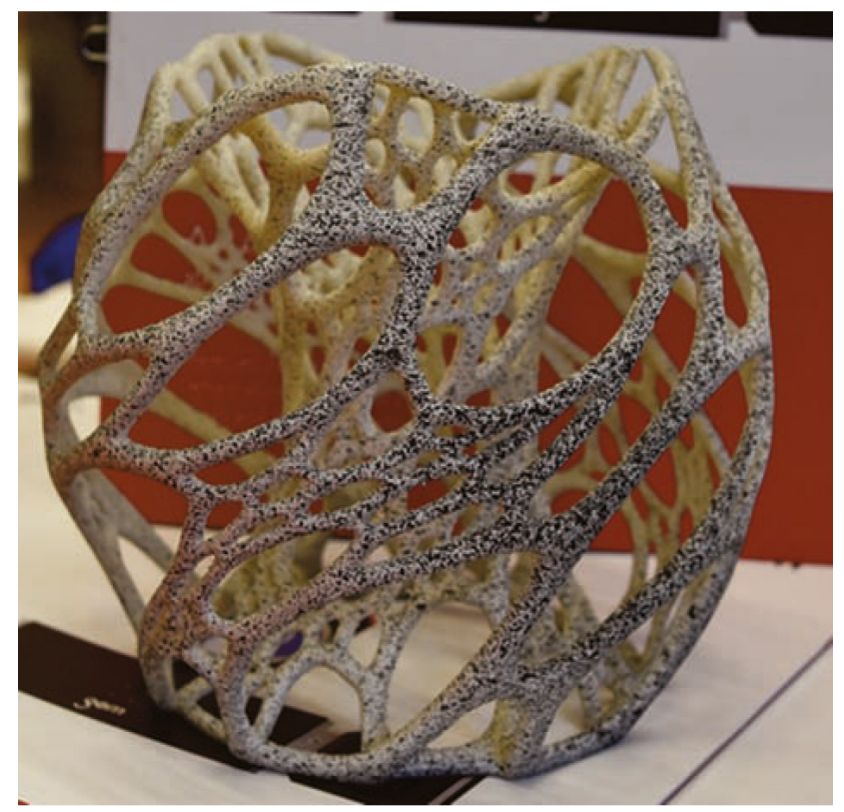

Figure 11. The printed three-dimensional bionic specimen (high: $130 \mathrm{~mm}$ ) 
For the cylinder specimen scan, the accuracy results were totalled between $+0.372 \mathrm{~mm}$ and $-0.200 \mathrm{~mm}$ on the cylinder root (Figure 12). The high dimensional deviation was occurred on the flat surface of cylinder $(-0.228 \mathrm{~mm})$ and a seam going along the whole specimen. The printed cylinder naked eye observations were nonhomogeneous, rugged surface. For the bionic specimen, the biggest dimensional deviation was occurred on the top specimen surface $(-0.507 \mathrm{~mm})$ (Figure 13). For the three-dimensional air turbine head specimen, the biggest dimensional deviation was totalled between +0.136 and $-0.162 \mathrm{~mm}$ (Figure 14).

It was noticed that the models printed in FDM technology are characterized by some big areas with the high deformation; therefore, general dimensional accuracy equal to ca. $\pm 0.1 \mathrm{~mm}$ with some big areas with a lower accuracy up to $\pm 0.5 \mathrm{~mm}$.

Table 2. The minimum and maximum accuracy deviation of space specimen printed in FDM technology

\begin{tabular}{|l|c|c|c|}
\hline $\begin{array}{l}\text { FDM technology } \\
\text { nominal } \\
\text { accuracy } \pm \mathbf{0 , 2 4 1} \\
\text { mm }\end{array}$ & $\begin{array}{c}\text { Cylinder specimen } \\
\text { layer thickness } \mathbf{0 . 2 5 4} \mathbf{~ m m}\end{array}$ & $\begin{array}{c}\text { Bionic specimen } \\
\text { layer thickness } \mathbf{0 . 2 5 4} \mathbf{~ m m}\end{array}$ & $\begin{array}{c}\text { Air turbine head specimen } \\
\text { layer thickness } \mathbf{0 . 2 5 4} \mathbf{~ m m}\end{array}$ \\
\hline $\begin{array}{l}\text { Maximum } \\
\text { deviation }[\mathrm{mm}]\end{array}$ & +0.372 & +0.507 & +0.136 \\
\hline $\begin{array}{l}\text { Minimum } \\
\text { deviation }[\mathrm{mm}]\end{array}$ & -0.200 & -0.227 & -0.162 \\
\hline
\end{tabular}

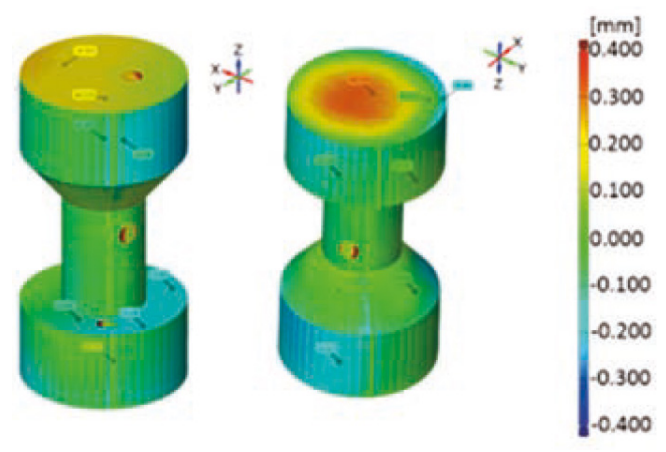

Figure 12. The three-dimensional cylinder specimen scan printed with nominal layer thickness $0.254 \mathrm{~mm}$ (FDM)
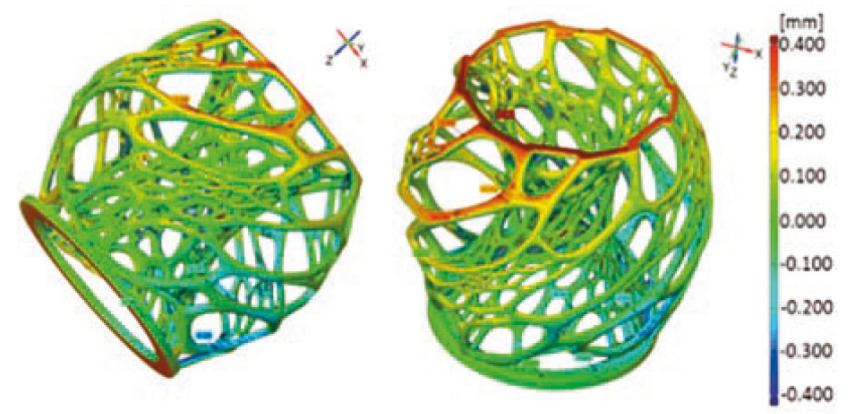

Figure 13. The three-dimensional bionic specimen scan with nominal layer thickness $0.254 \mathrm{~mm}$ (FDM) 

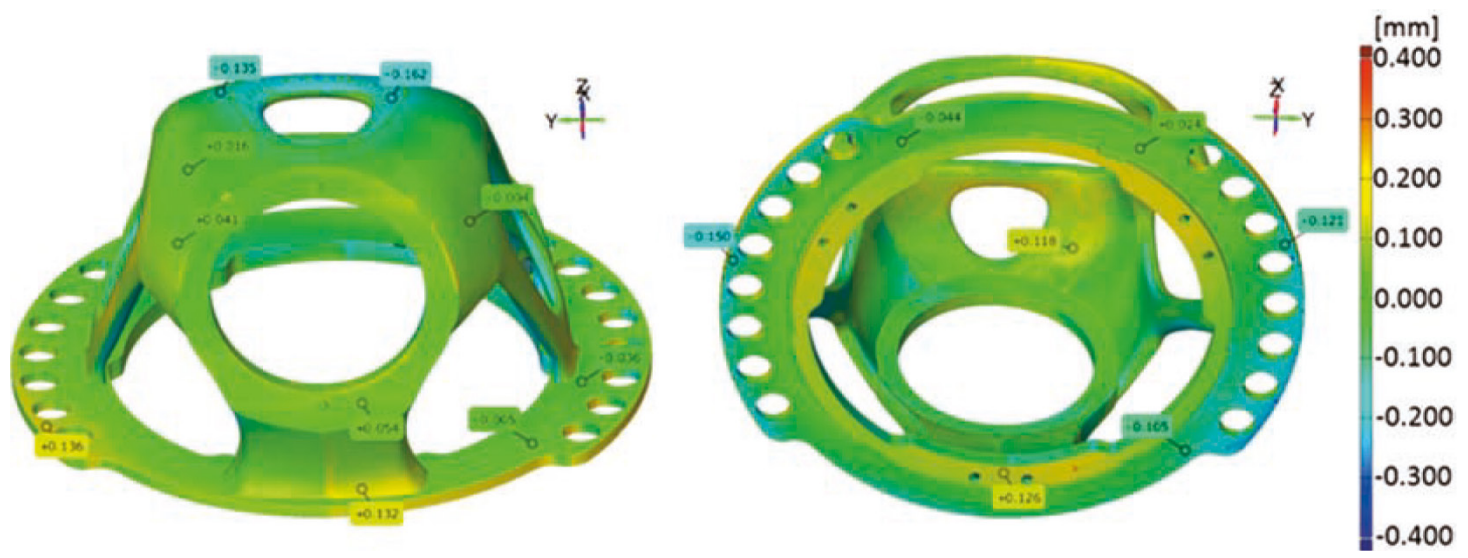

Figure 14. The three-dimensional air turbine head specimen scan with nominal layer thickness $0.254 \mathrm{~mm}$ (FDM)

\subsection{Geometric analysis - SLS technology}

The second step was to test both flat and three-dimensional specimens in the SLS technology (see Figure 15)[10]. The reference specimens were printed with $0.120 \mathrm{~mm}$ layer thickness on the EOSINT P 395 machine produced by EOS company. The nominal printing machine accuracy is $\pm 0.3 \mathrm{~mm}$. All results are gathered in Table 3 and demonstrates on the pictures below (see from Figure 16 to Figure 18).

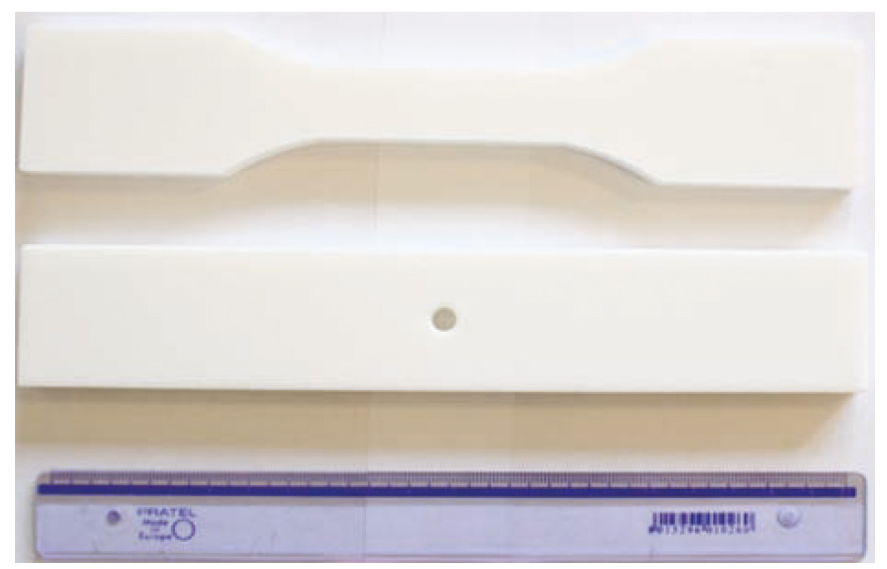

Figure 15. The dumbbell and rectangular prism with hole specimens printed in the SLS technology

For the dumbbell specimen, an accuracy results were between $+0.201 \mathrm{~mm}$ and $-0.359 \mathrm{~mm}$ and were detected in the similar areas as in the FDM (Figure 16). For the rectangular prism with a hole specimen, an accuracy results were between $+0.221 \mathrm{~mm}$ on the specimen edges and $-0.301 \mathrm{~mm}$ on the surface connected with the printing table (Figure 17). A deviation culmination was occurred in the same areas as for dumbbell specimen. For the air turbine head specimen, the biggest dimensional deviation was between +0.290 and $-0.297 \mathrm{~mm}$ (Figure 18).

The common feature for all SLS printed specimens is general dimensional accuracy equal to ca. $\pm 0.05 \mathrm{~mm}$ with some areas with a lower accuracy up to $\pm 0.5 \mathrm{~mm}$. 
Table 3. The minimum and maximum accuracy deviation of the flat and three-dimensional specimens printed in the SLS technology

\begin{tabular}{|l|c|c|c|}
\hline $\begin{array}{l}\text { SLS technology } \\
\text { nominal accuracy } \pm \mathbf{0 . 3} \\
\mathbf{m m}\end{array}$ & $\begin{array}{c}\text { Dumbbell specimen } \\
\text { layer thickness 0.120 } \\
\mathbf{~ m m}\end{array}$ & $\begin{array}{c}\text { Rectangular prism with } \\
\text { hole specimen } \\
\text { layer thickness } \mathbf{0 . 1 2 0} \mathbf{~ m m}\end{array}$ & $\begin{array}{c}\text { Air turbine head } \\
\text { specimen } \\
\text { layer thickness 0.120 } \\
\text { mm }\end{array}$ \\
\hline Maximum deviation $[\mathrm{mm}]$ & +0.372 & +0.507 & +0.290 \\
\hline Minimum deviation $[\mathrm{mm}]$ & -0.200 & -0.227 & -0.297 \\
\hline
\end{tabular}

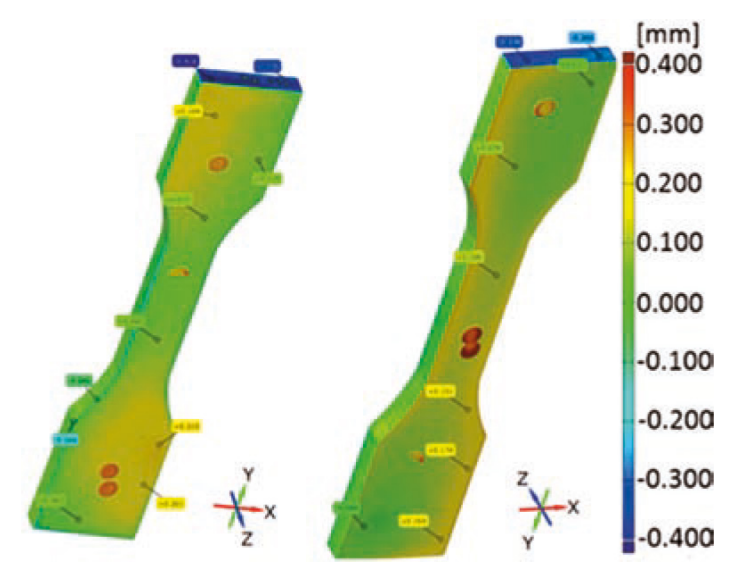

Figure 16. The dumbbell specimen scan printed with nominal layer thickness $0.120 \mathrm{~mm}$ (SLS)
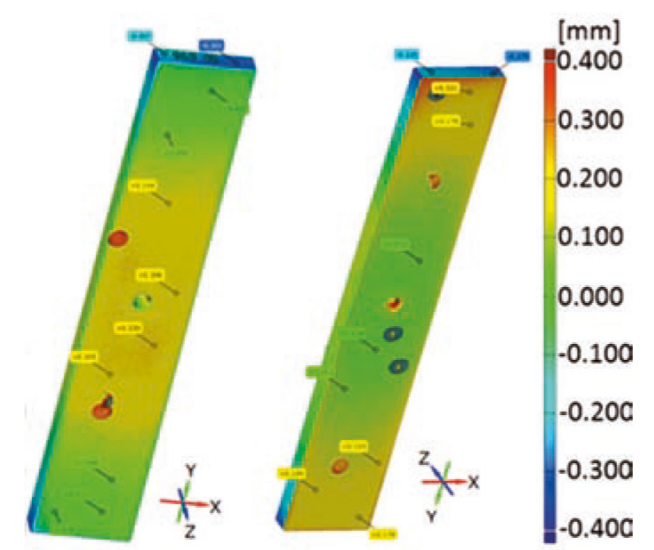

Figure 17. The rectangular prism with hole specimen scan printed with nominal layer thickness $0.120 \mathrm{~mm}$ (SLS) 

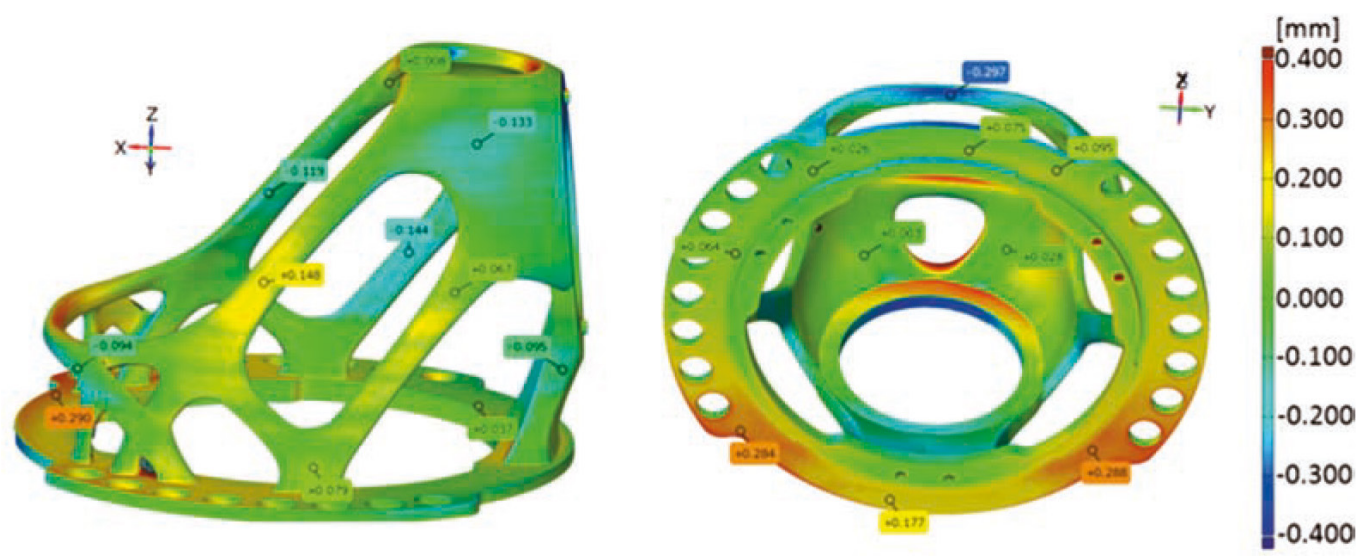

Figure 18. The three-dimensional air turbine head specimen scan with nominal layer thickness $0.120 \mathrm{~mm}$ (SLS)

\subsection{Geometric analysis - Material Jetting technology (PolyJet method)}

The last step was to test flat and three-dimensional specimens in the MJ technology. The reference specimens were printed with $0.028 \mathrm{~mm}$ layer thickness in the PolyJet method on the Objet 30 Prime machine produced by Stratasys company. The nominal printing machine accuracy is $\pm 0.1 \mathrm{~mm}$. Three dumbbell specimens and three rectangular prism specimens with a hole were printed (see Figure 19). All results are gathered in Table 4 and presented on the pictures below (see from Figure 20 to Figure 22).

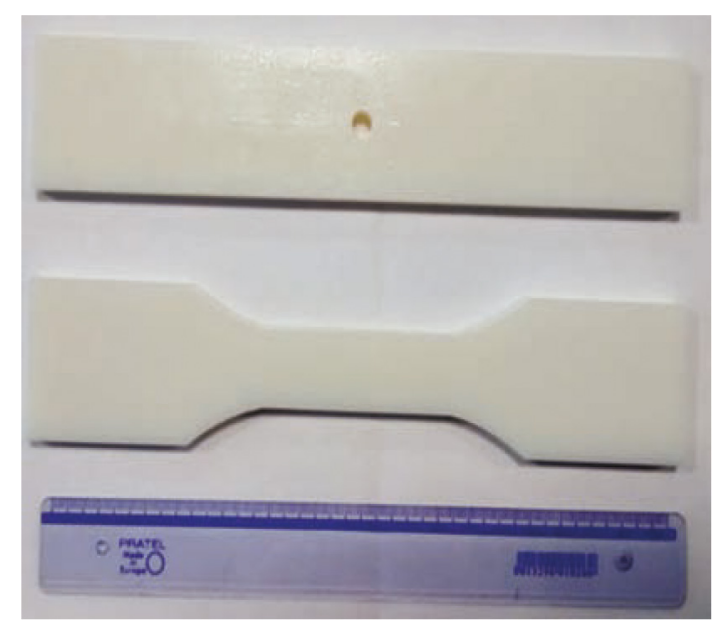

Figure 19. The dumbbell and rectangular prism with hole specimens printed in the Material Jetting (PolyJet) technology

For the dumbbell specimen, an accuracy results were between $+0.045 \mathrm{~mm}$ and $-0.010 \mathrm{~mm}$, deviations were similar on all specimen surfaces (Figure 20). For the rectangular prism with a hole specimen, an accuracy results were between $+0.065 \mathrm{~mm}$ and $-0.029 \mathrm{~mm}$. Deviations were also similar on all specimen surfaces (Figure 21). For the three-dimensional air turbine head specimen, the dimensional deviation was between +0.518 to $-0.507 \mathrm{~mm}$ (Figure 22). 
It was noticed that the FDM and the SLS technology printed models have much lower accuracy than the PolyJet method in the simple shape specimen. However, for the three-dimensional air turbine head specimen the lowest accuracy has PolyJet equal to ca. $\pm 0.5 \mathrm{~mm}$.

Table 4. The minimum and maximum accuracy deviation of flat and three-dimensional specimens printed in MJ PolyJet technology

\begin{tabular}{|l|c|c|c|}
\hline $\begin{array}{l}\text { PolyJet method } \\
\text { nominal accuracy } \\
\mathbf{\pm 0 . 1} \mathbf{~ m m}\end{array}$ & $\begin{array}{c}\text { Dumbbell specimen } \\
\text { layer thickness } \mathbf{0 . 0 2 8} \mathbf{~ m m}\end{array}$ & $\begin{array}{c}\text { Rectangular prism with } \\
\text { hole specimen } \\
\text { layer thickness } \mathbf{0 . 0 2 8} \mathbf{~ m m}\end{array}$ & $\begin{array}{c}\text { Air turbine head } \\
\text { specimen } \\
\text { layer thickness } \mathbf{0 . 0 2 8} \mathbf{~ m m}\end{array}$ \\
\hline $\begin{array}{l}\text { Maximum deviation } \\
{[\mathrm{mm}]}\end{array}$ & +0.045 & +0.065 & +0.518 \\
\hline $\begin{array}{l}\text { Minimum deviation } \\
{[\mathrm{mm}]}\end{array}$ & -0.010 & -0.029 & -0.507 \\
\hline
\end{tabular}

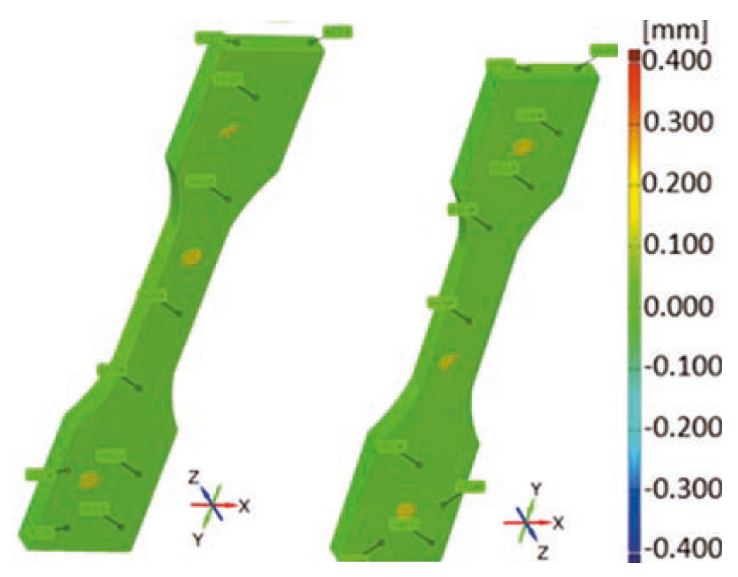

Figure 20. The dumbbell specimen scan printed with nominal layer thickness $0.028 \mathrm{~mm}$ (PolyJet method)
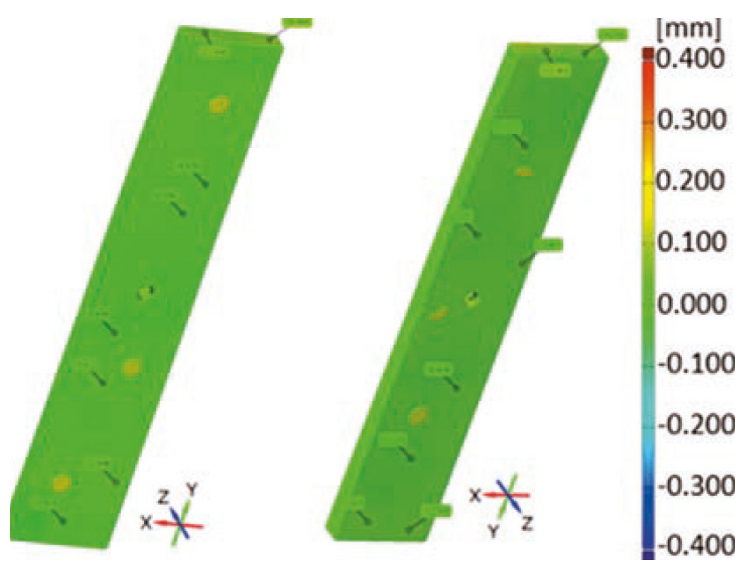

Figure 21. The rectangular prism with hole specimen scan printed with nominal layer thickness $0.028 \mathrm{~mm}$ (PolyJet method) 

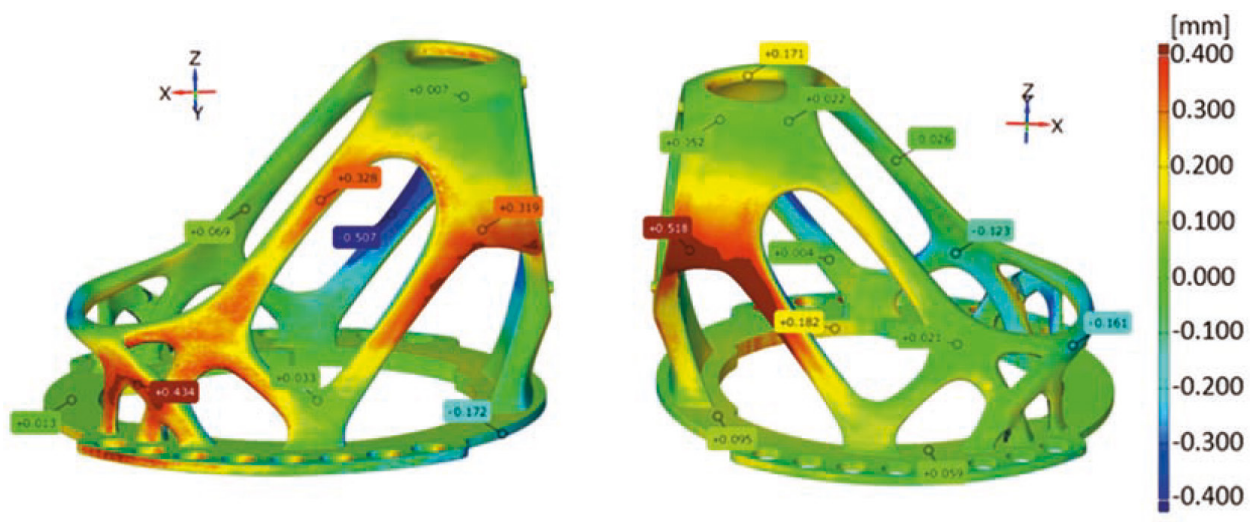

Figure 22. The three-dimensional air turbine head specimen scan with nominal layer thickness $0.028 \mathrm{~mm}$ (PolyJet method)

\section{PRINTING RESOLUTION COMPARISON}

The heat exchanger model (see Figure 23) was designed to verify printing resolution of three technologies - FDM, SLS and MJ [15]. Thin walls $(0.91 \mathrm{~mm})$ were arranged by turns with $2.71 \mathrm{~mm}$ space between them in an original size. The model was prepared in three different scales 1:1, 1:2 and 1:4 to check ability to print complicated shapes and easy remove of support.

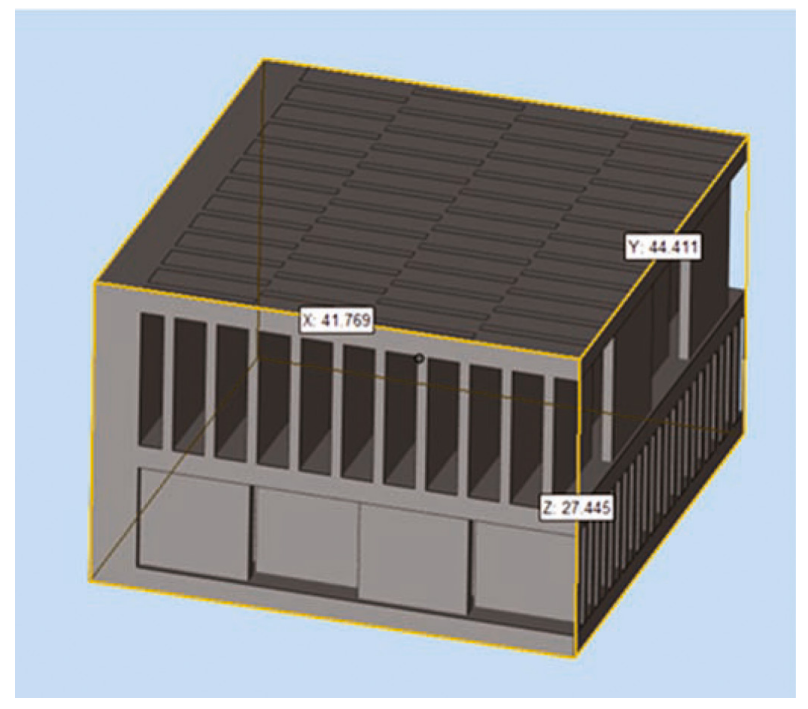

Figure 23. The heat exchanger model fragment in 1:1 scale (dimensions in $\mathrm{mm}$ )

Initially, the heat exchanger models were printed without use of support material in the FDM technology (see Figure 24). The model in 1:4 scale was printed with the lowest possible printer resolution (one layer of material) due to thicker walls compare to original one. A limited printer accuracy caused of warped walls. The heat exchanger model fragments in 1:2 and 1:1 scales collapsed under its own weight and further printing was impossible. 
Next, the heat exchanger models were printed with a support material (see Figure 25). The heat exchanger models in both 1:1 and 1:2 scales were printed properly however some walls were nicked probably due to the printing errors. The heat exchanger model fragment in 1:4 scale was partially destroyed during the support removing. This support was not entirely removed due to the narrow distance between walls $(0.68 \mathrm{~mm})$. Figure 26 shows full-dimension heat exchanger in 1:1 scale. The support material was not also entirely removed due to the complicated shape of model which hinder proper support-remover flow.

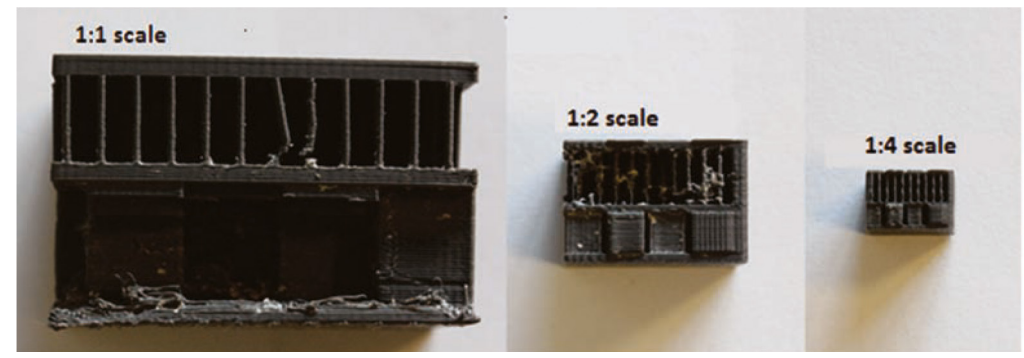

Figure 24. Fragments of the heat exchanger model printed in FDM technology (without support).

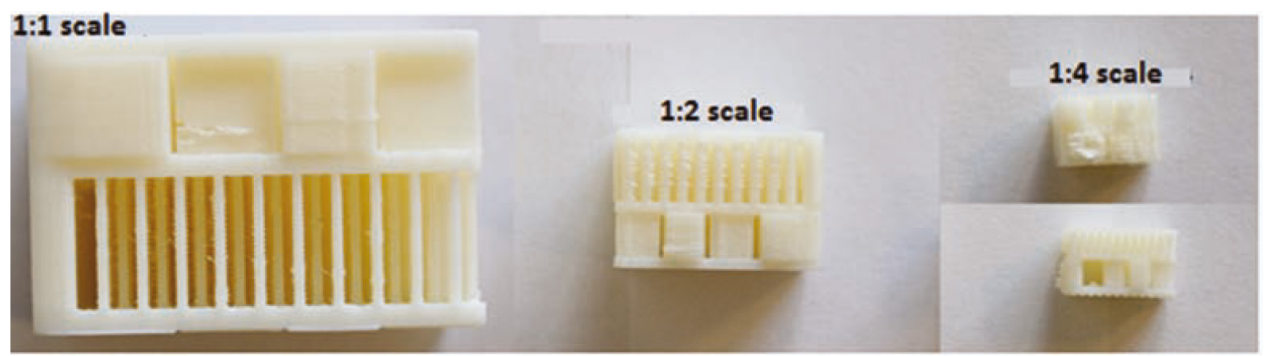

Figure 25. Fragments of the heat exchanger model printed in FDM technology (with support).

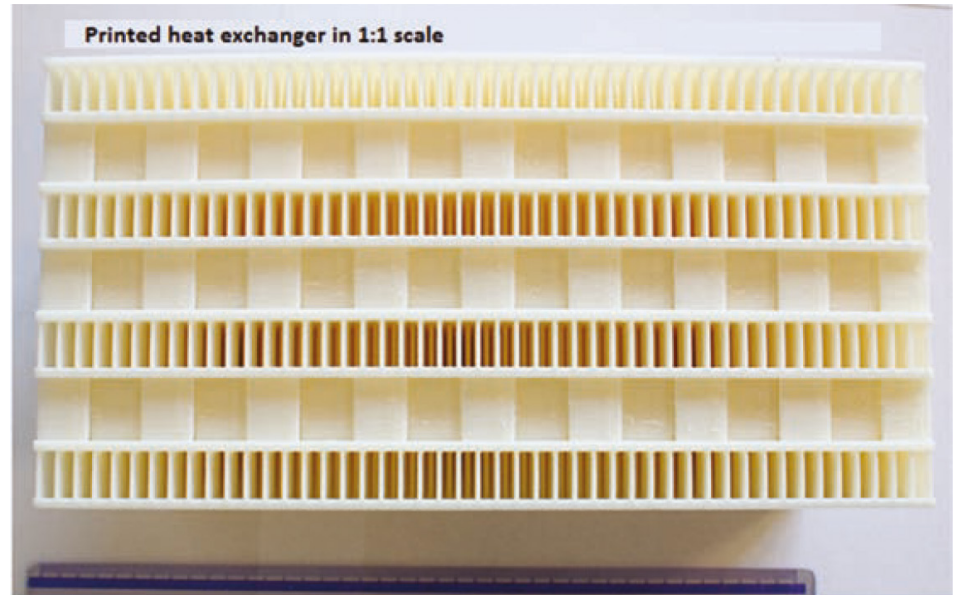

Figure 26. The heat exchanger model printed in 1:1 scale in FDM technology (with support) 
The following step was printed the heat exchanger in three scales in the SLS technology (see Figure 27). There is the same material for both model and support; therefore, there is no possibility to control the support build process.

The full-dimension heat exchanger was properly printed without any destroyed walls (see Figure 28). The support material was easily removed from the model in scales 1:1 and 1:2 however a support-powder left inside the model - powder was partially baked in the closed or hard to reach spaces what cause support-remove issues, whereas 1:4 scale model was completely baked.

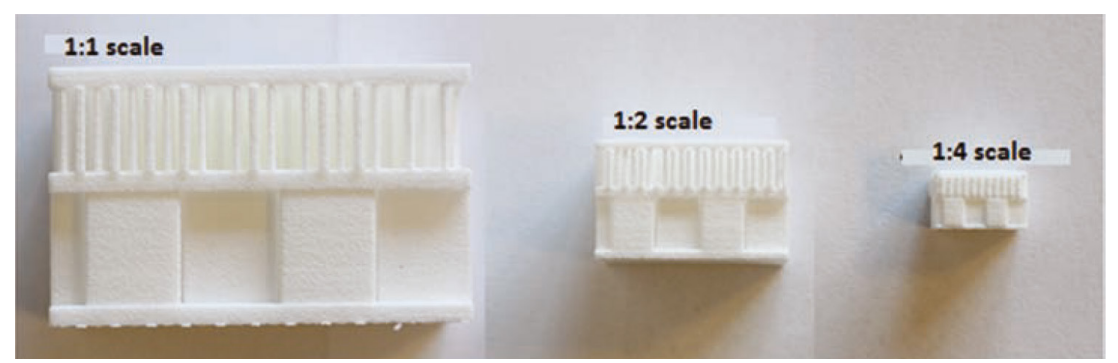

Figure 27. Fragments of heat exchanger model printed in the SLS technology

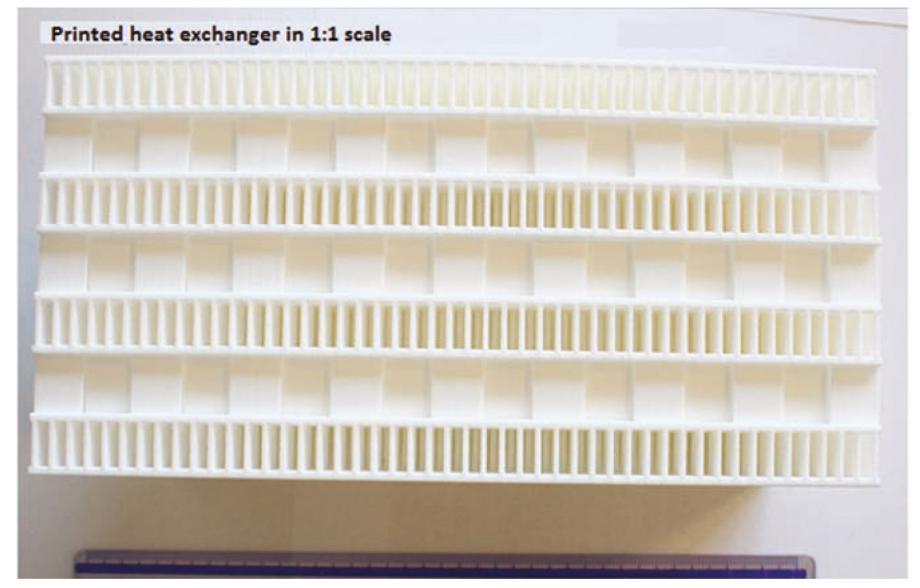

Figure 28. The heat exchanger model printed in 1:1 scale in the SLS technology

The last one was printed the heat exchanger in the MJ technology, PolyJet method. This method provides three supports materials removed by different fluids: SUP 705 - removed using water under pressure, SUP 706 - soluble using solvent, SUP 707 - soluble using still water. Both SUP 705 and 706 encounter a similar difficulty during remove process as in the SLS technology (see Figure 29) [14]. The model shape for 1:1 and 1:2 scales was properly imaged whereas in the model for 1:4 scale was hard to detect walls and spaces between them- this model was filled out with support material. SUP 707 material was removed from models in each scale with saved shape and lack of errors (see Figure 30).

Afterwards, the proper full-size heat exchanger was printed using VeroClear and VeroWhite Plus material with SUP 707 support material. Figure 31 demonstrates the model printed in VeroClear material with lack of support material inside the model. 


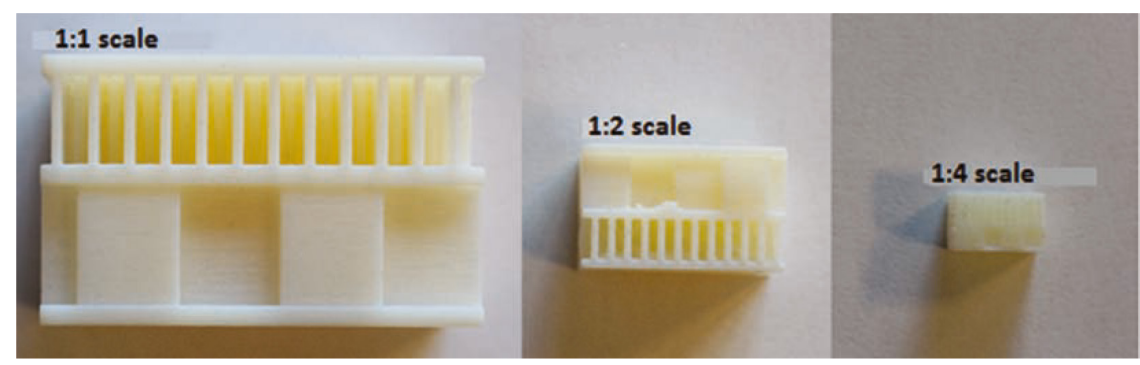

Figure 29. Fragments of the heat exchanger model printed in the PolyJet method (SUP 706 support)

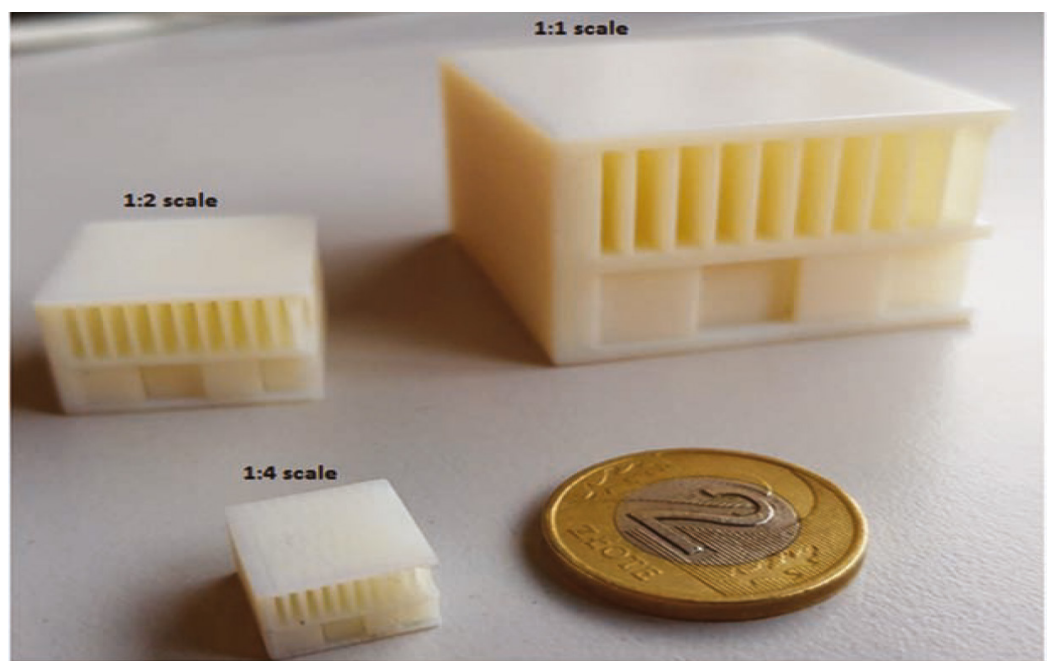

Figure 30. Fragments of the heat exchanger model printed in the PolyJet method (SUP 707 support)

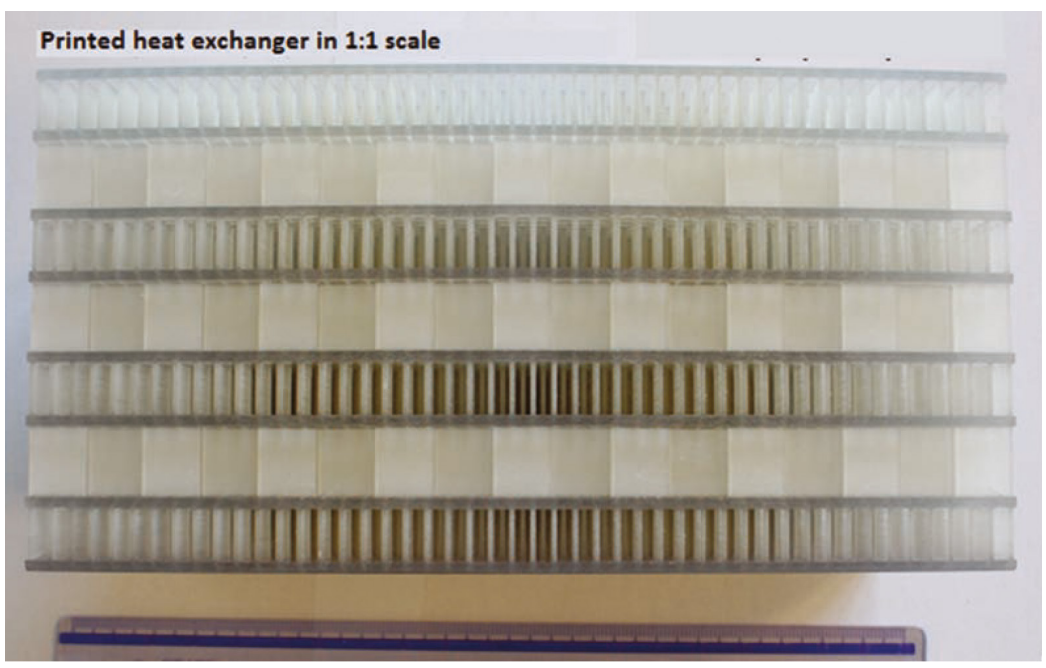

Figure 31. The heat exchanger model printed in 1:1 scale in the PolyJet method (SUP 707 support) 


\section{SUMMARY}

The primarily purpose of this article was to select the technology and material from three different $3 \mathrm{D}$ printing methods with the highest accuracy and printing resolution. The main aspects were considered as an accuracy and resolution however cost of machine, materials, service costs and time were also reflected. The conclusions were gathered in Table 5. The revision was created in particular to analyse of complicated shapes by the best parameters for each $3 \mathrm{D}$ printing method for the accessible printing machine; therefore, for printing process were used the minimal thickness of layers for each method for the concrete $3 \mathrm{~d}$ printing machine (not the same thickness for all). The stair effect is unmentioned due to ensure smooth surfaces by using the minimal thickness of printing layer [16]. The FDM technology provided a low machine and an exploitation cost in acceptable time however printed models were characterized by comparable accuracy and resolution in variety shapes. The SLS technology provided higher accuracy and resolution of models however, long pre-processing and post-processing time or low-volume production type were made this technology quite expensive for piece production. The Material Jetting technology (PolyJet method) were characterized by high accuracy and resolution of printed models especially for simple shapes. Moreover, MJ has rapid and average cost of printing single models and user-friendly printing machine.

Geometric analysis of the reference specimens demonstrated meaningful difference between the FDM, SLS and MJ technologies. It was concluded, printed models in the FDM technology were characterized by some big areas with high deformation. For all FDM printed specimens, the common feature was general dimensional accuracy equal to ca. $\pm 0.1 \mathrm{~mm}$ with some big areas with a lower accuracy up to $\pm 0.4 \mathrm{~mm}$. For all SLS printed specimens, the common feature was general dimensional accuracy equal to ca. $\pm 0.05 \mathrm{~mm}$ with some areas with lower accuracy up to $\pm 0.5 \mathrm{~mm}$. Presuming, as a production result that printed models in the FDM and SLS technology had much lower accuracy than the MJ technology (PolyJet method) for the simple shapes. For PolyJet printed specimens, the common feature was uniform surface deviation localization with general dimensional accuracy equal to ca. $\pm 0.05 \mathrm{~mm}$. However, for more complex shape like the air turbine head specimen were noticed some small areas with lower accuracy up to $\pm 0.5 \mathrm{~mm}$.

Printing resolutions were verified on the complicated shape printed in the different scales; therefore, it was discovered that variety of the support material and its removing method have a meaningful influence on the shape and quality of the printed model. For the FDM technology models were observed printing errors on the walls and support material was hard to remove in 1:4 scale and full-size models. For the SLS technology model, powder is build and support material in the same time and support powder were able to bake to the model in the closed or hard to reach spaces due to support-remove problems.

Nowadays, the matter of accuracy and the printing resolution comparison is extensively described in the studies of various centres, both domestic and foreign. Almost of the investigations have not released yet. In summary, the PolyJet method with SUP 707 material solely allows to achieve the proper complicated models with thin walls and narrow spaces between them in each scale and size in this review. 
Table 5. Comparison of the 3D printing technologies

\begin{tabular}{|c|c|c|c|}
\hline & FDM & SLS & Material Jetting (PolyJet) \\
\hline $\begin{array}{l}\text { Homogeneous of } \\
\text { printing models }\end{array}$ & low & average & high \\
\hline Thin wall models & yes (with support) & $\begin{array}{l}\text { yes (when distance between walls allows } \\
\text { to remove support powder) }\end{array}$ & $\begin{array}{l}\text { yes (with support made of the } \\
\text { water-soluble material } \\
\text { SUP707) }\end{array}$ \\
\hline Surface quality & $\begin{array}{c}\text { low (surface texture visible with the } \\
\text { naked eye) }\end{array}$ & average (powder grains feel by touch) & $\begin{array}{c}\text { high (elements with low } \\
\text { roughness) }\end{array}$ \\
\hline Support structures & reaction soluble material & non-sintered powder & $\begin{array}{l}\text { reaction and the water-soluble } \\
\text { material }\end{array}$ \\
\hline Materials multiplicity & mainly the ABS, PLA & mainly the PA & $\begin{array}{c}7 \text { basic materials and ca. } 100 \\
\text { digital materials }\end{array}$ \\
\hline 3D printer cost & low (5-30 thousand euro) & high (over 100 thousand euro) & $\begin{array}{l}\text { average (18-100 thousand } \\
\text { euro) }\end{array}$ \\
\hline Build material cost & average $(50-270$ euro $/ 1 \mathrm{~kg})$ & low (70 euro/ $1 \mathrm{~kg})$ & $\begin{array}{l}\text { high }(200 \text { euro } / \mathrm{lkg} \text {; } \\
\text { support } 110 \text { euro } / \mathrm{kg})\end{array}$ \\
\hline $\begin{array}{l}\text { Post processing } \\
\text { equipment }\end{array}$ & support material removes by a washer & $\begin{array}{l}\text { air compressor, vacuum cleaner, media } \\
\text { tumbling device, new and used powder } \\
\text { tanks, extractors }\end{array}$ & $\begin{array}{l}\text { support material removes by a } \\
\text { washer }\end{array}$ \\
\hline $\begin{array}{l}\text { Technology } \\
\text { destination }\end{array}$ & prototypes, low-volume production & series production & prototypes, piece production \\
\hline
\end{tabular}

\section{BIBLIOGRAPHY}

[1] Cantrell J. Rohde J., Damiani D. Experimental Characterization of the Mechanical Properties of 3D-Printed ABS and Polycarbonate Parts. United States of America: University of Florida, 2016.

[2] Redood B. Schoffer F., Garret B. The 3D printing handbook: Technologies, design and applications; Materials, Part one: 3D printing Technologies, design and application. Amsterdam: 3D HUBS, November 2017.

[3] Chee Kai Chua Murukeshan Vadakke Matham, Young-Jin Kim. World Scientific Series in 3D Printing - Vol. 2: Laser in 3D printing and manufacturing. Singapore: World Scientific Publishing, 2017. ISBN: 978-9814656429.

[4] Gibson I. Rosen D., Stucker B. Additive Manufacturing Technologies: 3D Printing, Rapid Prototyping, and Direct Digital Manufacturing 2nd ed: Material Jetting. London: Springer, 2015. ISBN 978-1493921126.

[5] Bibus Menos - FDM, PolyJet, SLS, DMLS - technology, materials,3d printers. [Online] https:// www.bibusmenos.pl/oferta/drukarki-3d/.

[6] Rabbit Form - Article about 3D printing. [Online] http://www.rabbitform.pl/category/artykuly.

[7] CadXpert - 3d printing technology and printer in FDM, SLA, SLS and Material Jetting. [Online] http://www.cadxpert.com.pl/.

[8] Drukarka3D - 3D printing technology - 3D SLA, SLS, FDM, DLSM, CJP, LOM, MJM, DLP, PolyJet. [Online] http://drukarka3d.pl/.

[9] Samuel N. Bernier, Bertier Luytd, and Tatiana Reinhard Design for 3D Printing: Scanning, Creating, Editing, Remixing, and Making in Three Dimensions, Canada: Marker Media, Inc. 2014. 
[10] Chee Kai Chua, Chee How Wong and Wai Yee Yeong Standards, Quality Control, and Measurement Sciences in 3D Printing and Additive Manufacturing, 2017.

[11] How to succeed when printing with ABS [Online] https://www.matterhackers.com/articles/how-tosucceed-when-printing-with-abs.

[12] Kawalec A., Oczoś Kazimierz E., Shaping of light metals, PWN, Warsaw 2012.

[13] Kluska E., Gruda P. The accuracy and the printing resolution comparison of different 3D printing technologies. Warsaw, Institute of Aviation, 2017.

[14] PolyJet Best Practise - Sup707 Water Soluble Support [Online] https://www.advancedtek.com/ wp-content/uploads/2016/08/Best_Practice_-_SUP707_Water Soluble_Support_-_Web_English_11-15.pdf.

[15] The 3D printing is more accurate than you think. [Online] http://swiatdruku3d.pl/druk-3d-dokladniejszy-niz-myslisz/?_sm_nck=1.

[16] Make beautiful 3D prints understanding the layer thickness [Online] https://www.sculpteo.com/ blog/2015/07/29/make-beautiful-3d-prints-understanding-the-layer-thickness/

\section{PORÓWNANIE DOKŁADNOŚCI I ROZDZIELCZOŚCI DRUKOWANYCH ELEMENTÓW 3D W WYBRANYCH TECHNOLOGIACH DRUKU}

\section{Streszczenie}

W niniejszym artykule przedstawiono fragment prac wykonanych w ramach projektu „Wykorzystanie metod druku 3D (rapid prototyping) w połączeniu z badaniami optycznymi do szybkiego optymalizowania przestrzennych modeli wykonanych w technologii przyrostowej”. Artykuł rozpoczyna się przeglądem trzech wybranych technologii drukowania 3D - Fused Deposition Modeling (FDM), Selective Laser Sintering (SLS) and Material Jetting (MJ), które w dalszej części zostały przetestowane pod kątem dokładności i rozdzielczości. Testy dokładności zostały przeprowadzone na płaskich próbkach referencyjnych obrazujących dodatkowo teksturę wydruku. Próbki te zeskanowano w celu zweryfikowania odchyłek wymiarowych. Rozdzielczość zweryfikowano na modelach wymiennika ciepła oraz głowicy elektrowni wiatrowej cechujących się skomplikowaną konstrukcją. Najwyższą dokładnością i zarazem rozdzielczością cechuje się technologia PolyJet wraz z próbkami wydrukowanymi na maszynie Objet Eden 260 VS z rozpuszczalnym w wodzie materiałem podporowym SUP 707.

Słowa kluczowe: drukowanie 3D, dokładność, rozdzielczość wydruków, skomplikowane kształty. 